\title{
Analysis of Nutritional Factors of Leaf Protein Concentrate (LPC) from Girardinia heterophylla (Decne)
} \author{
and V.K.Varshney ${ }^{3}$ \\ ${ }^{1}$ Department of Chemistry, M.K.P.(P.G.) College, Dehradun, Uttarakhand India \\ ${ }^{2}$ Forest Conservation Division, Ministry of Environment and Forest, Delhi India \\ ${ }^{3}$ Chemistry Division, Forest Research Institute (FRI), Dehradun, Uttarakhand India \\ ${ }^{4}$ Department of Chemistry, D.B.S.(P.G.) College, Dehradun, Uttarakhand India \\ ${ }^{5}$ Department of Chemistry, D.A.V.(P.G.) College, Dehradun, Uttarakhand India
}

Nisha Tripathi ${ }^{1} *$, C.J.Singh ${ }^{2}$, Lutful Haque Khan ${ }^{3}$, Sunita Kumar ${ }^{1}$, Rakesh Singh ${ }^{4}$, Prashant Singh $^{5}$

\begin{abstract}
Girardinia heterophylla (Decne), distributed extensively in Middle Himalayas, is a potential source of Leaf Protein Concentrate (LPC). Present study envisages the phytochemical investigations to assess the availability and commercial viability of LPC of G. heterophylla. Samples of plant leaves were collected from Mussoorie Hills of Uttarakhand (India) and contents of LPC were isolated. Proximate analysis of LPC for nitrogen, protein, fat, ash and carbohydrate content revealed their concentration in appreciable quantities making it a potential source of nonconventional protein. LPC has important biochemical characteristics, which establish the usefulness and potential of leaves of this plant to be used as animal fodder for better milk production and also as nutritionally rich source for protein for human consumption.
\end{abstract}

Keywords: Leaf Protein Concentrate, Girardinia heterophylla, non-conventional protein.

\section{INTRODUCTION}

Girardinia heterophylla Decne [1], commonly known as 'Dans Kandali' or Himalayan Nettle, belongs to Urticaceae family [2]. Its distribution in the Himalayas ranges from Kashmir (North Western Himalayas to Kumaun hills (Western Himalayas) of Uttarakhand with altitudinal range of 2100 to $3200 \mathrm{~m}$ [3]. It grows naturally around human habitats and can be seen growing extensively as an underutilized biomass in the in outskirts of the villages. It flourishes well in fertile soils with rich moisture content and appreciable concentration of lime. The plant has also been observed to thrive in areas having good forest canopy, with heavy leaf litter fall, and a high moisture level over a prolonged period of time.

Following morphological characteristic of plant distinguishes it in its habitat:

a. The leaves of the plant have a human palm like shape with sharp edges.

b. Height of plant ranges between 8-12 feet.

c. Plant bears tender needles on its leaves and stem (Fig. 1).

*Address correspondence to this author at the Department of Chemistry, M.K.P.(P.G.) College, Dehradun, Uttarakhand, India; Tel: 919873495609; Fax: 0135-2741147; E-mail: tripnisha30@gmail.com d. The hairs covering the stems and leaves are filled with fluid and break off when touched, and ejects a small hypodermic needle that allows the fluid to enter the skin and cause blistering.

As evident from the contemporary literate and traditional knowledge, the plant has remarkable role in the day to day life of various ethnic groups/ tribes of Uttarakhand. These forest dwellers have been using different parts of plant for their livelihood as well as health and other domestic purposes. The leaves of this plant are boiled and cooked for vegetables and also for preparing traditional recipes by the local forest dwellers [4]. Leaves are also a good source for protection against neoplastic, cardiovascular disorders and
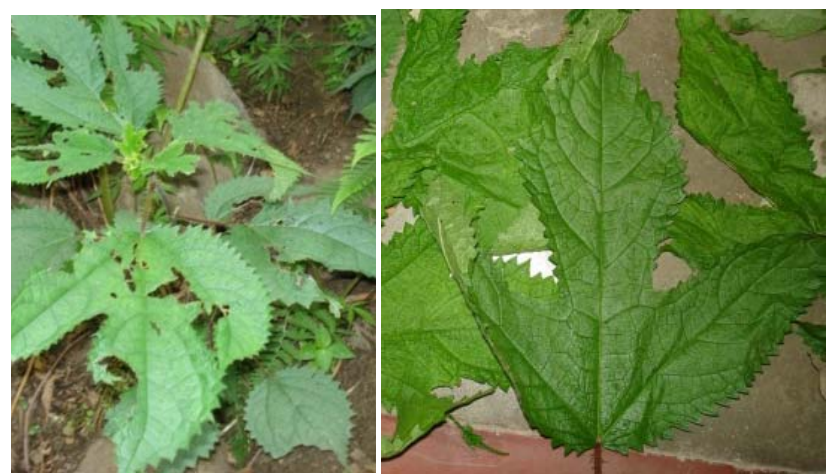

Fig. (1). Photographs of Girardinia heterophylla plant. 
immune deficiency. Studies on animals revealed that leaves of the plant have anti-tumoural activity and strong mutagenic activity $[5,6]$ therefore the leaves of the plant can be used as a nutraceutical that demonstrate specific health or medical benefits including the prevention and treatment of disease beyond basic nutritional functions [7]. The whole plant (leaf and stem) is used as cattle fodder to improve milk production. Root and leaf extracts are taken orally to cure abdominal pain [8].

Among the unconventional sources of protein, Leaf Protein Concentrate (LPC) appears to have better potential in light of excessive photosynthesis and its abundant availability as green vegetation. Lactating animals feeding on nettles plant (Girardinia heterophylla) produce more milk. Today human live in a nutritional environment which completely differs from that for which our genetic constitution was selected [9]. In the present study, an assessment of nutritional value of leaves of the plant, i.e. per cent composition nitrogen, protein, carbohydrates, fat and ash contents was made by preparing LPC from the leaves of plant. Accordingly, potential of plant was assessed for its utilization as an alternative source of protein supplements for animals as well as humans.

\section{EXPERIMENTAL}

\section{Plant Samples Collection}

Leaves samples were collected in the month of November 2010 winter season from Mussoorie hills of Uttarakhand, India situated between altitudinal ranges of $2200 \mathrm{~m}$ to $2500 \mathrm{~m}$. Matured leaves of plant were collected in early morning for the purpose of present study.

\section{Preparation of LPC of Leaves of the Plant}

The procedure for extraction of LPC, as suggested by Pirie in (1957) [10] was employed for the present study. $100 \mathrm{~g}$ fresh and fully matured leaves were minced with water (1:9) in a mixer and squeezed using muslin cloth (Fig. 2). The extracts were heated at $80^{\circ} \mathrm{C}$ for $8-10$ minutes in a water bath to coagulate the protein. Each of the coagulated mass

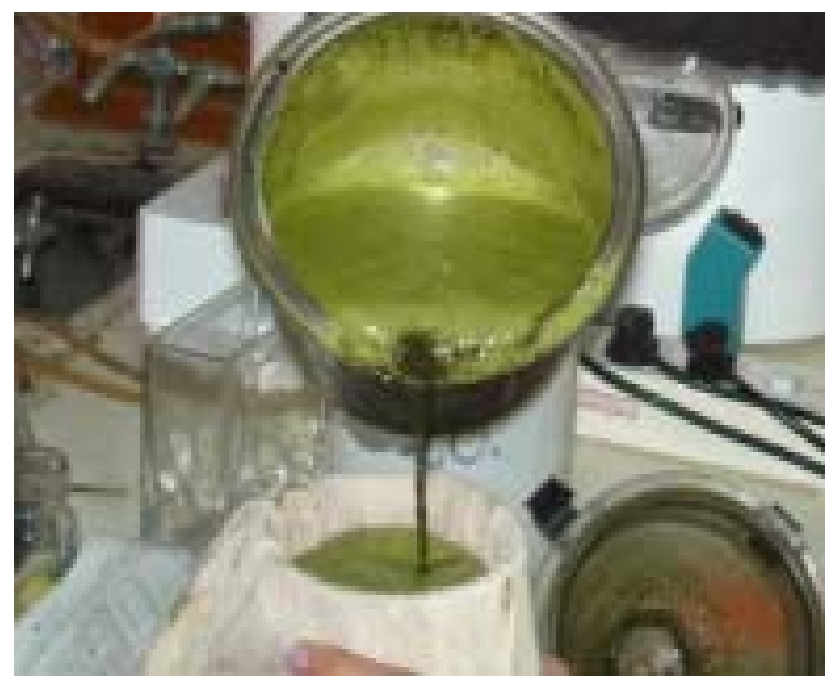

Fig. (2). Juice of Girardinia heterophylla Leaves. was conjugated at $10000 \mathrm{rpm}$ for 10 minutes, washed with distilled water and dried in hot air oven at $60^{\circ} \mathrm{C}$ for 30 minutes (Fig. 3). All the samples were stored at $-20^{\circ} \mathrm{C}$ until analyzed. Dried samples of LPCs were milled and triplicates samples were analyzed for their nutritional composition as per AOAC (Association of Analytical Chemists) methods (1975) [11].

Material, reagents and instruments used during preparation of the LPC in the laboratory are given below in (Table 1).

\section{RESULTS AND DISCUSSION}

LPC was analyzed for the assessment of percentage yield of nitrogen, protein, ash, fat and carbohydrate contents. It was observed that the amount of dry LPC recovered from Girardinia heterophylla was $8.00 \mathrm{~g}$ per $100 \mathrm{~g}$ fresh leaves. The data on yield expressed as amount of dry LPC recovered from $100 \mathrm{~g}$ leaves and nitrogen $(\mathrm{N} \%)$ content of LPC isolated from Girardinia heterophylla is presented in

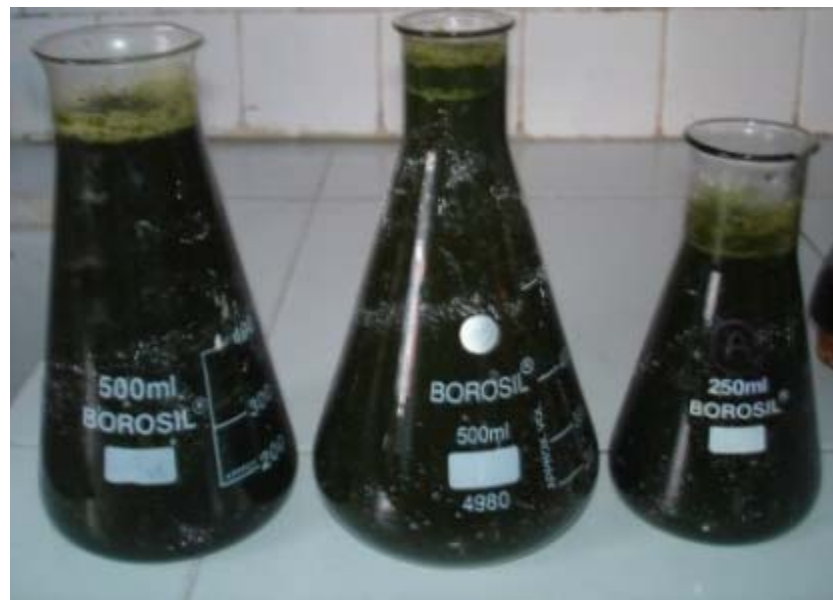

Fig. (3). Girardinia heterophylla Leaves- After Centrifugation.

Table1.

\begin{tabular}{|c|c|}
\hline S. No. & Material, reagents and instruments \\
\hline \hline 1 & Leaves of Girardinia heterophylla \\
\hline 2 & Ultracentrifuge \\
\hline 3 & Mixer \\
\hline 4 & Muslin cloth \\
\hline 5 & Water bath \\
\hline 6 & Acetone \\
\hline 7 & Weighing balance \\
\hline 8 & Distilled water \\
\hline 9 & Acetone \\
\hline 10 & Hot air oven \\
\hline 11 & Weighing balance \\
\hline 12 & Acidified water \\
\hline
\end{tabular}


(Table 2). The yield of the LPC is 8.00g and nitrogen content was found to be $7.30 \%$.

Table 3 summarizes the results of nutritional analysis of LPC. The crude protein content of the LPC isolated from Girardinia heterophylla was $45.75 \%$, fat content was $16.69 \%$, ash content was $2.86 \%$ and having $27.40 \%$ carbohydrate content. The high recovery of LPC with suitable nutritional composition as given in Table- 3 appears to be the potential source of LPC. In Girardinia heterophylla the LPC yield was high with a very good biochemical composition. Due to the high protein percentage (Fig. 4), it can be taken as protein supplement and also as a dietary supplement in vegetarian diet that contains no animal products [9]. Most vegetarian protein sources are healthier than non-vegetarian proteins, because they have less total fat, saturated fat, and cholesterol and more fiber than equivalent protein from animal sources [12-14]. Most individuals who consume vegetarian diets weigh less, have lower body mass index (BMI; in $\mathrm{kg} / \mathrm{m}^{2}$ ) values, and are healthier than those who don't [14-16]. A vegetarian diet can even foster weight loss [17]. LPC can be used as a dietary supplement which acts as a health promoting and disease preventing nutraceutical [7].

\section{CONCLUSION}

The LPC content of $8.0 \%$ per $100 \mathrm{~g}$ of leaves was obtained from the leaves of Girardinia heterophylla. Nitrogen contents, protein, fat, ash and carbohydrates were estimated to the tune of $7.30 \%, 45.75 \%, 16.69 \%, 2.86 \%$ and $27.40 \%$, respectively. The LPC contents of the plant are presented in Fig. (5). Keeping in view the appreciable protein content of LPC, the plant can be used as cattle fodder for improving milk production. It can be used in nutraceutical industries, food industries and fodder industries. In addition to this, plant can be used for commercial production in and thereby can be integrated with local livelihood.

Present investigation is confined to assess quality of protein available in LPC of plant. Results of quantitative analysis of LPC encourage further qualitative analysis of LPC of the plant to appropriately evaluate its potential to be used as complementary protein supplement and also as a dietary supplement for human as vegetarian diet.

\section{ACKNOWLEDGEMENT}

Authors are thankful to Uttarakhand Bamboo and Fiber Development Board for helping in the collection of plant sample.

\section{CONFLICT OF INTEREST}

The authors have no conflict of interest with any organizations or entities listed above.

\section{ABBREVIATIONS}

$\mathrm{LPC}=$ Leaf Protein Concentrate

Table 2. Percentage Yield and Nitrogen Content of LPC from Girardinia heterophylla

\begin{tabular}{|c|c|c|}
\hline Name of the plant species & Dry LPC (g) per 100g of leaves (g) $)^{\mathbf{a}}$ & Nitrogen in dry LPC (\%) $^{\mathbf{b}}$ \\
\hline \hline Girardinia heterophylla & 8.00 & 7.30 \\
\hline $\mathrm{a}, \mathrm{b}$ mean of three values & & \\
\hline
\end{tabular}

Table 3. Nutritional Composition of LPC Isolated from Girardinia heterophylla

\begin{tabular}{|c|c|c|c|c|c|}
\hline Name of plant Species & Crude protein $(\%)^{a}$ & Fat $(\%)^{\mathrm{a}}$ & $\operatorname{Ash}(\%)^{a}$ & Nitrogen (\%) & Carbohydrate(\%) \\
\hline Girardinia heterophylla & 45.75 & 16.69 & 2.86 & 7.30 & 27.40 \\
\hline
\end{tabular}

amean of the values given, ${ }^{b}$ carbohydrate [100- protein + Fat + Ash+ Nitrogen content].

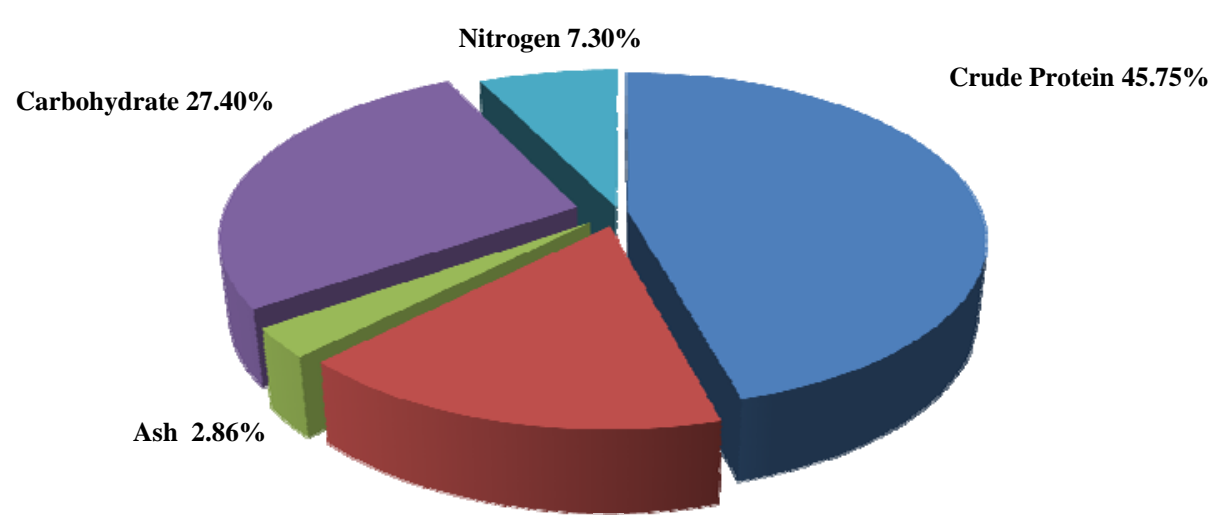

Fat $16.69 \%$

Fig. (4). Nutritional composition of Leaf Protein Concentrate (Per cent). 


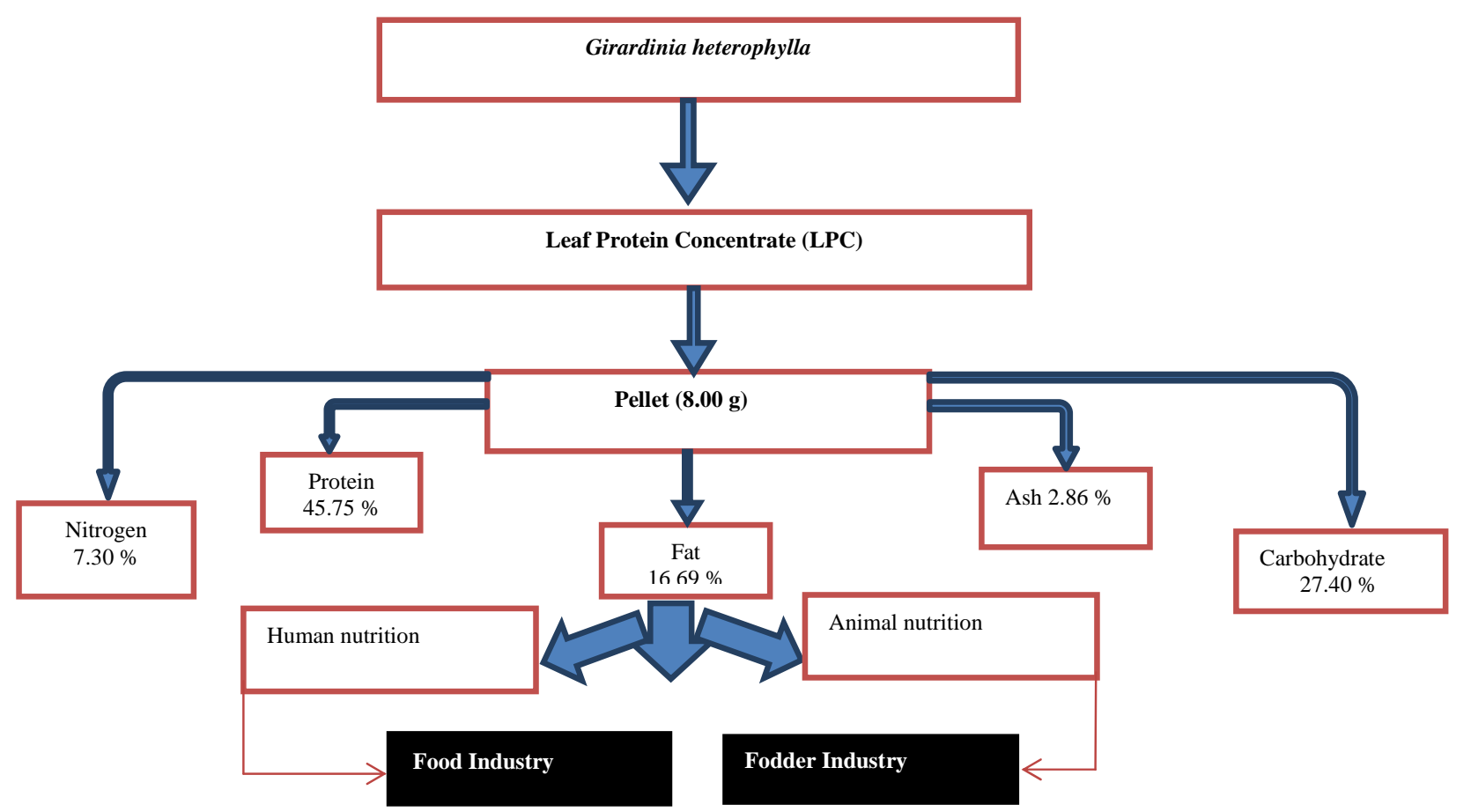

Fig. (5). LPC of Girardinia heterophylla and (\%) of Nitrogen, Protein, Fat, Ash and Carbohydrate.

\section{REFERENCES}

[1] Khare PC. Indian medicinal plants. An illustrated dictionary. Girardinia heterophylla Decne, Springer-Verlag Berlin Heidelberg: New York. 2007.

[2] Bhatt V, Purohit KV. Floristic structure and phytodiversity along an elevational gradient Peepal Koti-Joshimath area of Garhwal Himalaya, India. Nat Sci 2009; 7(9): 63-74.

[3] Annonymous. A dictionary of Indian Raw Materials, Wealth of India Publication CSIR, New Delhi. 1989: p 419.

[4] FREEP-GHNP. Research and monitoring component. WII Dehradun 1999

[5] Wetherilt H. Assessment of the nutritional properties and antitumoural activity of the common nettle grown in Turkey, Ph.D thesis, Hacettepe University, Ankara 1989.

[6] Karkaya S, EI SN. Determination of antimutagenic effects of some foods and drinks in vitro binding capacity of some dietary fibers to mutagens. J Nutr Diet 2000; 29(2): 4.

[7] Sharma R. Nutraceuticals and Nutraceuticals supplementation criteria in cancer: a literature survey. Open Nutra J 2009; 2: $92-$ 106.

[8] Gaur RD, Bhatt KC, Tiwari JK. An ethnobotanical study of Uttar Pradesh Himalaya in relation to veterinary medicines. J Ind Botan Soc 1992; 72: 139-44.
[9] Singh RB, Takahashi T, Nakaoka T, et al. Nutrition in Transition from Homo sapiens to Home economics. Open Nutra J 2013; 6: 617.

[10] Pirie NW. Leaf protein as human feed. Food Manuf 1957; 32: 416.

[11] AOAC (Association of analytical chemists), Official methods of analysis. $12^{\text {th }}$ ed., Washington, D.C., U.S.A. 1975: p. 1.

[12] Haddad EH, Tanzman JS. What do vegetarians in the United States eat? Am J Clin Nutr 2003; 78: 626S-32S.

[13] Janelle KC, Barr SI. Nutrient intakes and eating behavior scores of vegetarian and nonvegetarian women. J Am Diet Assoc 1995; 95: 180-6.

[14] Bedford JL, Barr SI. Diets and selected lifestyle practices of selfdefined adult vegetarians from a population-based sample suggest they are more 'health conscious'. Int J Behav Nutr Phys Act 2005; 2: 4 .

[15] Alewaeters K, Clarys P, Hebbelinck M, Deriemaeker P, Clarys JP. Cross-sectional analysis of BMI and some lifestyle variables in Flemish vegetarians compared with non-vegetarians. Ergonomics 2005; 48: 1433-44.

[16] Key T, Davey G. Prevalence of obesity is low in people who do not eat meat. BMJ 1996; 313: 816-7.

[17] Turner-McGrievy CM, Barnard ND, Scialli AR. A two year randomized weight loss trial comparing a vegan a diet to a more moderate low-fat diet. Obesity 2007; 15: 2276-81.

This is an open access article licensed under the terms of the Creative Commons Attribution Non-Commercial License (http://creativecommons.org/licenses/by-nc/3.0/) which permits unrestricted, non-commercial use, distribution and reproduction in any medium, provided the work is properly cited. 